IZA DP No. 10099

'Even' After Access to Financial Services?

Ricocheting Gender Equations

Shoba Arun

Samuel Annim

Thankom Arun

July 2016 


\title{
'Even' After Access to Financial Services? Ricocheting Gender Equations
}

\author{
Shoba Arun \\ Manchester Metropolitan University \\ Samuel Annim \\ University of Cape Coast \\ Thankom Arun \\ University of Essex \\ and IZA
}

Discussion Paper No. 10099

July 2016

IZA

P.O. Box 7240

53072 Bonn

Germany

Phone: +49-228-3894-0

Fax: +49-228-3894-180

E-mail: iza@iza.org

Any opinions expressed here are those of the author(s) and not those of IZA. Research published in this series may include views on policy, but the institute itself takes no institutional policy positions. The IZA research network is committed to the IZA Guiding Principles of Research Integrity.

The Institute for the Study of Labor (IZA) in Bonn is a local and virtual international research center and a place of communication between science, politics and business. IZA is an independent nonprofit organization supported by Deutsche Post Foundation. The center is associated with the University of Bonn and offers a stimulating research environment through its international network, workshops and conferences, data service, project support, research visits and doctoral program. IZA engages in (i) original and internationally competitive research in all fields of labor economics, (ii) development of policy concepts, and (iii) dissemination of research results and concepts to the interested public.

IZA Discussion Papers often represent preliminary work and are circulated to encourage discussion. Citation of such a paper should account for its provisional character. A revised version may be available directly from the author. 


\section{ABSTRACT}

\section{'Even' After Access to Financial Services? Ricocheting Gender Equations*}

The paper focuses on women's financial behaviour in their use of higher order financial services in Ghana and South Africa, inviting a gendered and social analysis of deconstructing financial behaviour. Women in South Africa are more likely to use general financial products than in Ghana, though in general more men use advanced investment products. Race has an important effect in South Africa. Much of these gender differentials is related to differences in gendered behaviour, yet generalizations on how gender relates to risk aversion is not supported. Rather non-financial approaches may explain how social relations propel women's decision to prioritise the use of financial services as a result of ascribed gender and social roles. These findings contribute to the debates on the feminisation of finance, as women are increasingly interpellated as financial subjects, manifesting the gendered organisation of global financial structures that operate on gendered norms and behaviour.

JEL Classification: $\quad$ O16, O55, A14, B54

Keywords: gender, access to finance, risk, Ghana and South Africa

Corresponding author:

Thankom Arun

Essex Business School

University of Essex

Wivenhoe Park

Colchester CO4 3SQ

United Kingdom

E-mail: tarun@essex.ac.uk

* This is a substantially revised and amended version of the paper previously circulated as IZA Discussion Paper No. 7688 ("Is Climbing Difficult? A Gendered Analysis on the Use of Financial Services in Ghana and South Africa"). 


\section{Introduction}

In pursuing financial inclusion globally and ensuring gender equality, integrating women into global finance has been gaining much focus as they have been traditionally overlooked financial ‘subjects'. Yet a cursory glance on literature around gender and finance points to how women’s relation to finance is largely ambivalent, and pronounced more so through gender differences in financial behaviour (Powell and Ansic 1997; Schubert 2006) and how the organisation of global finance is gendered (Assassi 2009). This paper contributes to debates on gender and finance, by examining access to and use of different types of financial services and the sources of gender differentials in two vibrant economies of sub-Saharan Africa, Ghana and South Africa. Section 1 of the paper sets the context of the two countries in terms of differences and similarities, and Section 2 reviews the literature on gendered access to finance and financial services, examining some of the tropes in the discussion. Section 3 outlines the data and methods used, while Section 4 discusses the findings before providing conclusions in Section 5.

\section{The context of Ghana and South Africa}

The paper focuses on two countries in sub-saharan Africa based on convergences and divergences in their economic and financial sectors, and gender equality. At the macroeconomic level, South Africa and Ghana have exhibited converging trends in growth patterns, with increasing economic growth and reduction in poverty, but marked by stark patterns of socioeconomic inequality (Annim et al 2012 : Abdolai and Hulme 2014). Ghana has made strides in reducing poverty to less than 30 percent of the population, and acquiring the lower middleincome status. Similarly post-apartheid South Africa, an upper middle income country in terms of per capita income, is characterised by multiple forms of inequality (UNDP 2014; May 1998; Barbarin and Lechter 2011) and importantly, race, class and gender are persistent determinants for the prevailing political, social and economic inequalities (Kehler 2001). Women's unequal status in the economic and social sector, particularly in the developing contexts, is very much 
documented as they are concentrated in more precarious forms of employment with lower levels of earnings and assets (Heintz 2005). Thus evidence of gender inequality is further manifested through intimate partner violence, the maternal mortality rate and income inequality in women and female headed households (Deghaye, McKenzie and Chirawu 2014). Since the women’s financial and economic security issues are disproportionately represented in the labour and credit markets, the similarities and differences in relation to socioeconomic patterns of inequality, and its implications for financial inclusion particularly for women form an important background to this study. It also renders comparisons significant within these two countries per se not just for exploring gendered access to resources, but also to locate the nature of these, within policies on gender equality and financial inclusion.

Both countries exhibit some divergences in terms of regulation and policies in the financial sector, but do present higher levels of financial exclusion as in many developing countries. Intermittent downturns in access and use of financial services have been observed in South Africa, irrespective of the fact that the country enjoys better access to finance than other countries in the region. For instance, the FinMark Trust (2009) reports a 3 per cent drop in the proportion of South Africans using a bank service, and studies focus on the demand-side factors of access to financial markets (Annim et al., 2012; Kostov et al. 2011; Narain 2009). Since 1987, Ghana has implemented reforms in the financial sector; interest rate caps and allocation of credit to priority sectors were abolished as part of the reform. Recent legislation on venture capital (2004), insolvency (2006) and credit reporting (2006) shows the desire to create an enabling atmosphere in Ghana. Further, changes in the regulatory framework ensure significant improvements in the legal basis for financial intermediation particularly in prudential supervision, capital adequacy, bank risk management, and more on-site supervision. The financial environment in South Africa has also witnessed substantial changes in financial regulations and innovations, and partnerships across all financial institutions (Annim et al. 
2012), such as the Mzansi initiative introduced in 2004 to reach the "unbanked”. While it is apparent that in both Ghana and South Africa conscious efforts have been instituted to ensure access to financial services, it is worth noting that this does not automatically translate to use of financial services. Next, some emerging themes on the gender in relation to financial use is discussed.

\section{Gender and Financial Use: Through the lens of Ambivalence}

By now there is an exhaustive body of scholarship on women's access to finance, with significant attention on supply side factors in terms of gendered access to different forms of finance. Much of this debate is located within the entrepreneurship (and gender) literature as to how gender mediates external business finance (Brush 2012; Marlow and Swail 2015) or economic psychological evidence in finance and risk taking ( Schubert 2006; Meier-Pesti and Penz 2008). In developing countries, national contexts do influence the role of gender in determining access to business finance (Shaw, Carter and Lam 2010; Mayoux 2001). In high income countries 87.4 per cent of women have an account with a formal financial institution, whereas the figure is 21.5 per cent in sub-Saharan Africa (GFI, 2011). In terms of using the accounts for business purposes, the figures for high-income countries and sub-Saharan Africa are 22.1 per cent and 4 per cent respectively. In Ghana, social networks play an important role in women's access to bank financing (Kuado 2009). The starting point for this paper is that the role of gender in the demand for finance is constituitive of gender relations, roles and behaviour. It is important to unravel the nature of social relations of finance particularly in the context of deepening processes of global finance whereby Roberts (2015) argues that in multiple ways, gender is linked to the process of financial deepening, often to the detriment of women.

In all, observed gender differences in demand for finance and credit are a consequence of choice, outcome of systemic disadvantage or financial discrimination (Hulten 2012). Thus generalizations 
in the literature that ricochet from demand factors, to supply of financial services point to much ambivalence in situating women's use of financial services. However an emerging body of scholarship points to how the organisation of global finance is gendered as financial markets are often a male dominated sphere characterised by risk taking, speculation and profits (Assassi 2009). Chant and Sweetman (2012) critique the instrumental policies of 'smart economics' that 'fix' gender rather than the economy, through investing in women for global growth. The gender bias of financial system is significant, as modern systems of finance and credit are based on private property forms, which in effect is gendered, and has historically limited direct access to financial resources (Assassi 2009). Other gendered, cultural and social factors in the differential use of financial services, that are intangible and innate, need to be deconstructed and situated wthin the wider discourse of social relations and asset building.

As discussed above, one of the features of formal finance has been risk related behaviour, with large part of literature on entrepreneurship theorizing alluding to the genderd nature of risk aversion (Caliendo et al.2009; Sapienza, Zingales, and Maestripieri 2009). Evidence on gendered investment behaviour further point to how women more often choose assets which impose few risks and refrain from selecting higher risk assets through attitudes, and preferred practice (MeierPesti and Penz 2008; Jianakoplos and Bernasek 1998). Most explanations for gendered risk aversion often point to biological based essentialist analyses of gender roles within frames of social reproduction, the gendered division of labour and socialisation (Anselmi and Law 1998) that endorse women's inability to prioritise economic performance or growth objectives or lower engagement with economic risk taking compared to the dominant masculine traits (Marlow and Swail 2014). Results from abstract gamble experiments as social habits, women exhibit more risk aversion than men (Eckel and Grossman 2002).

In all, Beck's argument that risk is constitutive of cultural perceptions and shaped by social norms and expectations is critical here. As Marlow and Swail (2014) purport attributing risk averseness 
as an explanation or attribute is to be explored to avoid being defined as an inherent characteristic. Thus risk needs to be understood in the wider framework of social relations and gendered behaviour and responses to institutional norms and practices. Interestingly many sociological and cultural studies on finance including those of anthropologists, have turned to the interaction and mutual constitution of human behaviours in financial systems (Maurer 2005). This situates markets and finance as a social construction, situating the role of social networks and microstructures to understand financial subjects and behaviour. As Kuado (2009) finds in Ghana, female entrepreneurs tend to have more difficulties in accessing bank financing but they compensate by cultivating social relationships and using the social capital derived from them as a resource leveraging mechanism. This points to gendered norms of financial structures which is inflected by gendered and social behaviours in investments and use of financial services, resulting from ascribed gender and social roles as explored in this paper.

The next section discusses the data and methods used in the paper.

\section{Data and Methods}

This paper uses data from the FinScope surveys in Ghana and South Africa in 2010, an initiative of the FinMark Trust (an independent trust funded primarily by UKaid, the United Kingdom’s Department for International Development). The survey is nationally representative and conducted in a number of sub-Saharan African countries, on several issues including financial services and socioeconomic characteristics.

The survey, drawn from the individual adult population (above 15 and 16 years respectively in Ghana and South Africa), is based on a multi-stage sampling approach, 3,648 respondents were interviewed in Ghana and 3,900 in South Africa. Some country-specific issues were incorporated, for example an important element of the South African financial market is the introduction of Mzansi accounts. This analysis takes this into account by classifying access to 
Mzansi account as part of the 'none' category. The content of the FinScope instrument is as follows: (i) Household register; (ii) Financial literacy; (iii) Overall financial perception; (iv) Banking penetration (transaction channels, Mzansi and credit and loans); (v) Insurance products and services (funeral cover and retirement/pension); (vi) Investment/savings; (vii) Lifestyles; (viii) Access to amenities and use of information, communication and technology (ICT); (ix) Sources of money; and (x) Personal and household's socio-economic and demographic characteristics.

The analysis of this study is in twofold: (i) to determine the extent to which gender differences affect the use of these services and (ii) the extent to which observed characteristics introduced in the model explain the estimated coefficient of gender. In this regard, an ordered logit model for the three types of financial products is estimated as the first step and then a non-linear version of the Blinder-Oaxaca decomposition technique that decomposes the coefficient ascertained from the ordered logit model into two parts. 
Table 1: Classification of Type and Levels of Use of Financial Service

\begin{tabular}{|c|c|c|c|c|}
\hline \multirow{2}{*}{$\begin{array}{c}\text { Types of } \\
\text { Financial Service }\end{array}$} & \multicolumn{4}{|c|}{ Levels } \\
\hline & Pre(None) & Basic & Intermediate & Advance \\
\hline $\begin{array}{l}\text { General Accounts } \\
\text { and Services }\end{array}$ & $\begin{array}{l}\text { Mzansi and } \\
\text { Loan of a } \\
\text { Friend }\end{array}$ & $\begin{array}{l}\text { ATM, Savings } \\
\text { Book, Post Office } \\
\text { Account, Savings } \\
\text { and Transaction } \\
\text { Account, Employer } \\
\text { or Microcredit } \\
\text { Institution }\end{array}$ & $\begin{array}{l}\text { Debit Card, Current or } \\
\text { Cheque account, Credit } \\
\text { Card, Fixed Deposit, } \\
\text { Mortgage, Money for house } \\
\text { either from Government or } \\
\text { Employer and Personal } \\
\text { Loan }\end{array}$ & $\begin{array}{l}\text { Money Market, } \\
\text { Vehicle Finance or } \\
\text { Overdraft }\end{array}$ \\
\hline Investment & None & $\begin{array}{l}\text { Lending to others } \\
\text { and benefitting from } \\
\text { their profit and } \\
\text { being a member of } \\
\text { Stokvel/savings club } \\
\text { or burial society }\end{array}$ & $\begin{array}{l}\text { Investment in } \\
\text { property/house/flat that you } \\
\text { rent out, Unit trusts, } \\
\text { Investment in } \\
\text { cattle/livestock and } \\
\text { Collectables } \\
\text { (antiques/carpets/paintings/a } \\
\text { rt/coins/stamps) }\end{array}$ & $\begin{array}{l}\text { Timeshares, Holiday } \\
\text { home/investment in a } \\
\text { second home, } \\
\text { Investment in vacant } \\
\text { land, farm land, own } \\
\text { business, someone } \\
\text { else's business, shares } \\
\text { on the stock market } \\
\text { and off-shore } \\
\text { investment }\end{array}$ \\
\hline Insurance & None & $\begin{array}{l}\text { Funeral Policy with } \\
\text { a big institution, } \\
\text { Provident or } \\
\text { Pension Fund and } \\
\text { Educational Policy }\end{array}$ & $\begin{array}{l}\text { Life Assurance Policy, } \\
\text { Retirement Annuity, } \\
\text { Endowment/Investment } \\
\text { Policy, Homeowner's } \\
\text { insurance, Medical Aid, } \\
\text { Insurance taken out to } \\
\text { maintain credit payments } \\
\text { and Car Insurance }\end{array}$ & $\begin{array}{l}\text { Hospital Plan and } \\
\text { Medical or Household } \\
\text { content Insurance }\end{array}$ \\
\hline
\end{tabular}

Three outcome variables (types of financial services used) were constructed from the section on financial products and: (i) level of use of general accounts and services, (ii) level of use of insurance services; and (iii) level of use of investment services. Each of the financial products was first classified under one of these three headings. Then, following Annim et al. (2012), they were further classified into levels of use, namely: pre-account (none) (coded as 1); basic account (coded as 2); intermediate account (coded as 3); and advanced account (coded as 4). Respondents were asked their gender and we recoded this variable assigning 1 to females and 0 to males. The paper also controls for other variables such as age, income level, education and household size. We also controlled for regional and province effects by introducing a set of dummy variables. 
The study controlled for supply-side factors that affect the decision to use financial services. Specifically, the supply-side factors considered are: working hours of financial institutions; cost of service provision (interest rate and other transaction costs); return on deposits; staff attitude; travelling distance to financial institutions; time spent in engaging in a financial service; and sense of intimidation in the banking hall. The variables were captured by counting the number of such constraints faced by each individual. In the case of Ghana, eight such questions were identified, with five in South Africa. Table 1 presents how the various services were categorized.

The choice of ordered logit is appropriate because the dependent variables are ranked from 1 to 4 in each case, with none or pre account coded as 1 , basic account as 2, intermediate account as 3 and advanced account as 4 . We then estimate the odds ratios since the coefficients in themselves mean very little in terms of interpretation. To decompose the coefficient of sex (gender) into the relative contributions of observed and unobserved characteristics of males and females, we employ the Blinder-Oaxaca decomposition for nonlinear regression models (Sinning, Hahn, \& Bauer, 2008). This procedure is used instead of the usual Blinder -Oaxaca decomposition because it allows us to decompose the outcome variable of a non-linear dependent variable into a part that is explained by observed characteristics and part attributable to estimated coefficients.

Given an ordered logit regression model regression model for two groups $g=(m, f)$,because the outcome variable is nonlinear the conditional expectation of $E\left(Y_{i g} \mid X_{i g}\right)$, may differ from $\overline{\boldsymbol{X}}_{g} \hat{\beta}_{g}$ (Sinning et al., 2008). (Sinning et al., 2008) obtains a general version of the Blinder BlinderOaxaca decomposition as: 
$\Delta_{m}^{N L}=\left[E_{\beta_{m}}\left(Y_{i A} \mid \boldsymbol{X}_{i m}\right)-E_{\beta m}\left(Y_{i f} \mid \boldsymbol{X}_{i f}\right)\right]+\left[E_{\beta m}\left(Y_{i f} \mid \boldsymbol{X}_{i f}\right)-E_{\beta f}\left(Y_{i f} \mid \boldsymbol{X}_{i f}\right)\right]$

where $E_{\beta_{g}}\left(Y_{i g} \mid \boldsymbol{X}_{i g}\right)$ is the conditional expectation of $Y_{i g}$ and $E_{\beta_{g}}\left(Y_{i h} \mid \boldsymbol{X}_{i h}\right)$ represents the conditional expectation of $Y_{i h}$ evaluated at the parameter vector $\beta_{g}$. In this set up $g, h=(m, f)$ and $g \neq h$. The first term on the right hand side displays the differential in the outcome variables (in this case general account and services, insurance and investment services) between $m$ and $f$ as a result of differences in the explanatory variables in $\boldsymbol{X}_{i g}$, and the other term shows the part differential that is due to differences of the coefficient. Given the above general procedure we estimate the ologit version of the techniques as:

$$
\begin{gathered}
\frac{1}{N_{g}} \Sigma_{1=1}^{N}\left[\left\{\Lambda\left(\widehat{\mu_{1}}-\boldsymbol{X}_{i g} \widehat{\beta_{g}}\right)-\Lambda\left(-\boldsymbol{X}_{i g} \widehat{\beta_{g}}\right)\right\}+2\left\{\Lambda\left(\widehat{\mu_{2}}-\boldsymbol{X}_{i g} \widehat{\beta_{g}}\right)-\Lambda\left(\widehat{\mu_{1}}-\boldsymbol{X}_{i g} \widehat{\beta_{g}}\right)\right\}\right. \\
\left.+\cdots J\left\{1-\Lambda\left(\widehat{\mu_{J-1}}-\boldsymbol{X}_{i g} \widehat{\beta_{g}}\right)\right\}\right]
\end{gathered}
$$

Where $J$ is the number of possible outcomes and $\widehat{\mu}, \ldots \mu_{J-1}$ are the estimated threshold values of the ordered logit and a is the cumulative logistic density function. Next, the results and discussion of findings is provided.

\section{Findings and Discussion}

The results from the analysis are preceded by a descriptive overview of the use of financial services across the different types and the levels of each type. Figures 1 to 3 present the descriptive results based on gender differences for both Ghana and South Africa. Consistent with the respective FinScope reports, the proportion of females in the sample is greater than males in both Ghana and South Africa. Table 2 and 3 present the distribution of the variables used across gender, showing significant differences for males and females. 
Table 2: Summary statistics of variables-Ghana model

\begin{tabular}{|c|c|c|}
\hline & Male & Female \\
\hline & $45 \%$ & $55 \%$ \\
\hline \multicolumn{3}{|l|}{ INVESTMENT } \\
\hline Pre & 1211 & 1506 \\
\hline Basic & 86 & 117 \\
\hline Intermediate & 46 & 26 \\
\hline Advanced & 42 & 38 \\
\hline \multicolumn{3}{|c|}{ Pearson chi2 $(3)=12.9558 \quad \operatorname{Pr}=0.005$} \\
\hline INSURANCE & Male & Female \\
\hline Pre & 1228 & 1603 \\
\hline Basic & 7 & 7 \\
\hline Intermediate & 137 & 65 \\
\hline Advanced & 13 & 12 \\
\hline \multicolumn{3}{|c|}{ Pearson chi2(3) $=46.1337 \quad \operatorname{Pr}=0.000$} \\
\hline GENERAL ACCOUNT AND SERVICES & Male & Female \\
\hline Pre & 732 & 1001 \\
\hline Basic & 336 & 446 \\
\hline Intermediate & 275 & 195 \\
\hline Advanced & 42 & 45 \\
\hline \multicolumn{3}{|c|}{ Pearson chi2 $(3)=41.6622 \quad \operatorname{Pr}=0.000$} \\
\hline MARITAL STATUS & Male & Female \\
\hline Not married & 608 & 777 \\
\hline Married & 777 & 910 \\
\hline \multicolumn{3}{|c|}{ Pearson chi2 $(1)=1.4322 \operatorname{Pr}=0.231$} \\
\hline LEVEL OF EDUCATION & Male & Female \\
\hline Pre school & 303 & 451 \\
\hline Basic school & 665 & 923 \\
\hline Secondary sch. & 265 & 239 \\
\hline Post-secondary & 52 & 26 \\
\hline University & 100 & 48 \\
\hline \multicolumn{3}{|c|}{ Pearson chi2 $(4)=70.2355 \quad \operatorname{Pr}=0.000$} \\
\hline INCOME LEVEL & Male & Female \\
\hline No income & 179 & 303 \\
\hline Below GHC600 per month & 1143 & 1356 \\
\hline GHC601-1200 per month & 45 & 23 \\
\hline GHC1201-1800 per month & 11 & 4 \\
\hline over 1801 & 7 & 1 \\
\hline \multicolumn{3}{|c|}{ Pearson chi2 $(4)=35.5948 \quad \operatorname{Pr}=\mathbf{0 . 0 0 0}$} \\
\hline Total & 1385 & 1687 \\
\hline
\end{tabular}


Table 3: Summary statistics of variables-South Africa model

\begin{tabular}{|c|c|c|}
\hline & Male & Female \\
\hline & $36 \%$ & $63 \%$ \\
\hline \multicolumn{3}{|l|}{ INVESTMENT } \\
\hline Pre & 550 & 906 \\
\hline Basic & 234 & 590 \\
\hline Intermediate & 181 & 278 \\
\hline Advance & 170 & 214 \\
\hline \multicolumn{3}{|c|}{ Pearson chi2(3) $=36.0995 \quad$ Pr $=0.000$} \\
\hline INSURANCE & Male & Female \\
\hline Pre & 497 & 845 \\
\hline Basic & 529 & 999 \\
\hline Intermediate & 72 & 111 \\
\hline Advance & 37 & 33 \\
\hline \multicolumn{3}{|c|}{ Pearson chi2(3) $=11.2012 \quad$ Pr $=0.011$} \\
\hline GENERAL ACCOUNT AND SERVICES & Male & Female \\
\hline Pre & 386 & 703 \\
\hline Basic & 217 & 399 \\
\hline Intermediate & 422 & 759 \\
\hline Advance & 110 & 127 \\
\hline Total & 1135 & 1988 \\
\hline \multicolumn{3}{|c|}{ Pearson chi2(3) $=11.2903 \quad \mathrm{Pr}=0.010$} \\
\hline MARITAL STATUS & Male & Female \\
\hline not married & 703 & 1237 \\
\hline married & 432 & 751 \\
\hline Total & 1135 & 1988 \\
\hline \multicolumn{3}{|c|}{ Pearson chi2(1) $=0.0249 \quad \operatorname{Pr}=0.875$} \\
\hline INCOME LEVEL & Male & Female \\
\hline No Income & 190 & 360 \\
\hline Below Average & 203 & 318 \\
\hline Average & 70 & 347 \\
\hline Above Average & 347 & 621 \\
\hline High Income & 325 & 342 \\
\hline Total & 1135 & 1988 \\
\hline \multicolumn{3}{|c|}{ Pearson chi2(4) $=115.5599 \quad \operatorname{Pr}=0.000$} \\
\hline LEVEL OF EDUCATION & Male & Female \\
\hline Primary Sch & 165 & 375 \\
\hline Secondary sch & 403 & 745 \\
\hline Technical sch & 40 & 27 \\
\hline Matriculation and some univer. & 527 & 841 \\
\hline \multicolumn{3}{|c|}{ Pearson chi2(3) $=27.1918 \quad \mathrm{Pr}=0.000$} \\
\hline Total & 1135 & 1988 \\
\hline
\end{tabular}


Figure 1 shows that more than half of both men and women in Ghana either do not use a general account or service, or use a pre-account. This pattern is also observed for the use of investment products (Figure 2) and insurance services (Figure 3).

For South Africa, we observe a 1 percent gender difference in all the levels for the general accounts and services, with the exception of the advanced level where a 3 per cent difference in favour of men is observed. In sum, for general accounts and services, larger gender differences in favour of men are observed in Ghana relative to differences in South Africa. In spite of this, the Chi-square tests show that the gender difference is statistically significant in the two countries; suggesting that the difference is not by chance in either country and is therefore driven by either observed or unobserved factors.

Figure 2 shows that in South Africa, about half of both men and women do not use an investment product, while in Ghana only one out of ten people uses an investment product. Also from Figure 2, we observe a significant difference in the proportion of use of basic investment products in both Ghana and South Africa. While in South Africa about half of the adult population use some form of basic investment products, in Ghana less than 10 per cent of the adult population use a basic investment product. Thus a stark difference in gendered behaviour is noted. It is interesting that more females in both countries use basic investment products while more males in both countries use advanced investment products. Thus men are likely to have advanced investment products such as mutual fund, provident fund and ownership of treasury bills and shares and stocks. This is not surprising as many forms of financial behaviour are traditionally associated with the masculine sphere. This supports studies that financial markets are constructed as a rational masculinized and professional activity as a result of gender norms that are constituitive of gender roles (Assassi 2009; Doyle and Paludi 1991) and the social role theory where masculine attributes of risk taking, self-assertiveness, agency, and motivation to master are masculine attributes (Wilson and Daly 1985). As the results of our study show, the use of 
investment products such as the collection of antiques, unit trusts, livestock and so forth is more common among women (52\%) than men (50\%) in South Africa, which is in accord with stereotypes of female sex roles as being communal, selfless, and caring.

Figure 3 presents the descriptive analysis of the use of insurance services in Ghana and South Africa by gender. As with the observation on the use of investment products, Figure 3 shows that about half the adult population in South Africa uses insurance services, while in Ghana only 5 per cent and 11 per cent of the female and male adult population respectively use an insurance service. In terms of gender differences, 4 percent of females use intermediate insurance services, compared to 9 per cent of males. Though negligible, the proportion of males and females who use advanced insurance services in Ghana is the same for adult males and females that is 1 per cent. In South Africa, more males use advanced insurance services than do their female counterparts (Figure 3). However, in terms of basic insurance services such as funeral, provident, pension and education, the proportion of females using these services is greater than that of their male counterparts. The FinMark Trust (2011) report indicates that about 21 per cent of female patronise burial and funeral insurance services, compared to 11 per cent of males. As more females (29\%) than males (19\%) use basic insurance services, showing how definitions and perceptions of the propensity for risk are shaped by social norms and expectations. As Beck (2006) states, it is cultural perception and definition that constitute risk. Thus we see that even after access to basic financial services, women's attitude to financial services is closely associated with gender socialisation and attitudes to social risks such as death and illness, associated with caring and reproductive roles, rather than prioritising higher risk-related forms of economic investment. 


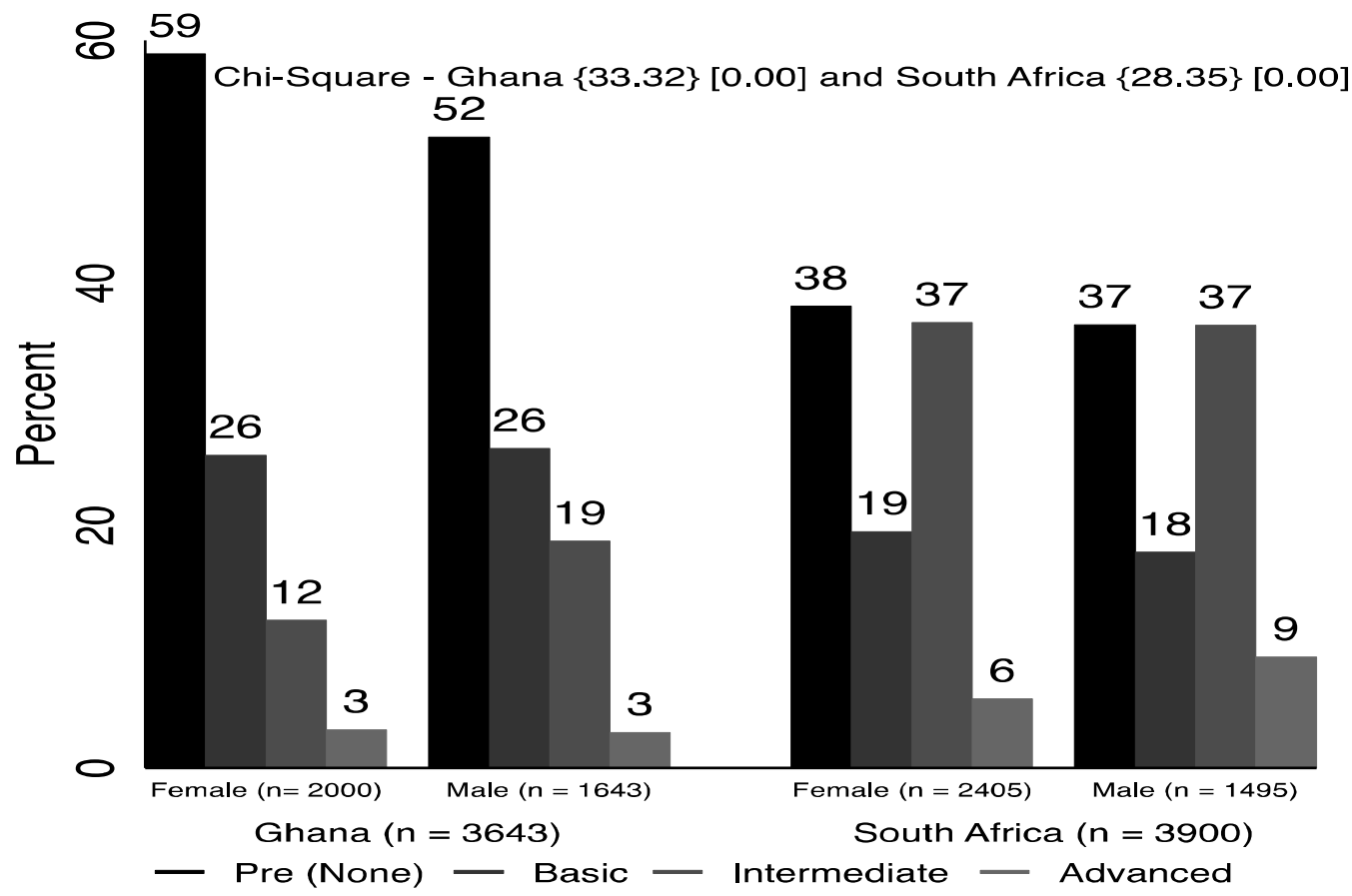

Figure 1: Levels of Use of General Accounts and Services by Sex in Ghana and South Africa in 2010

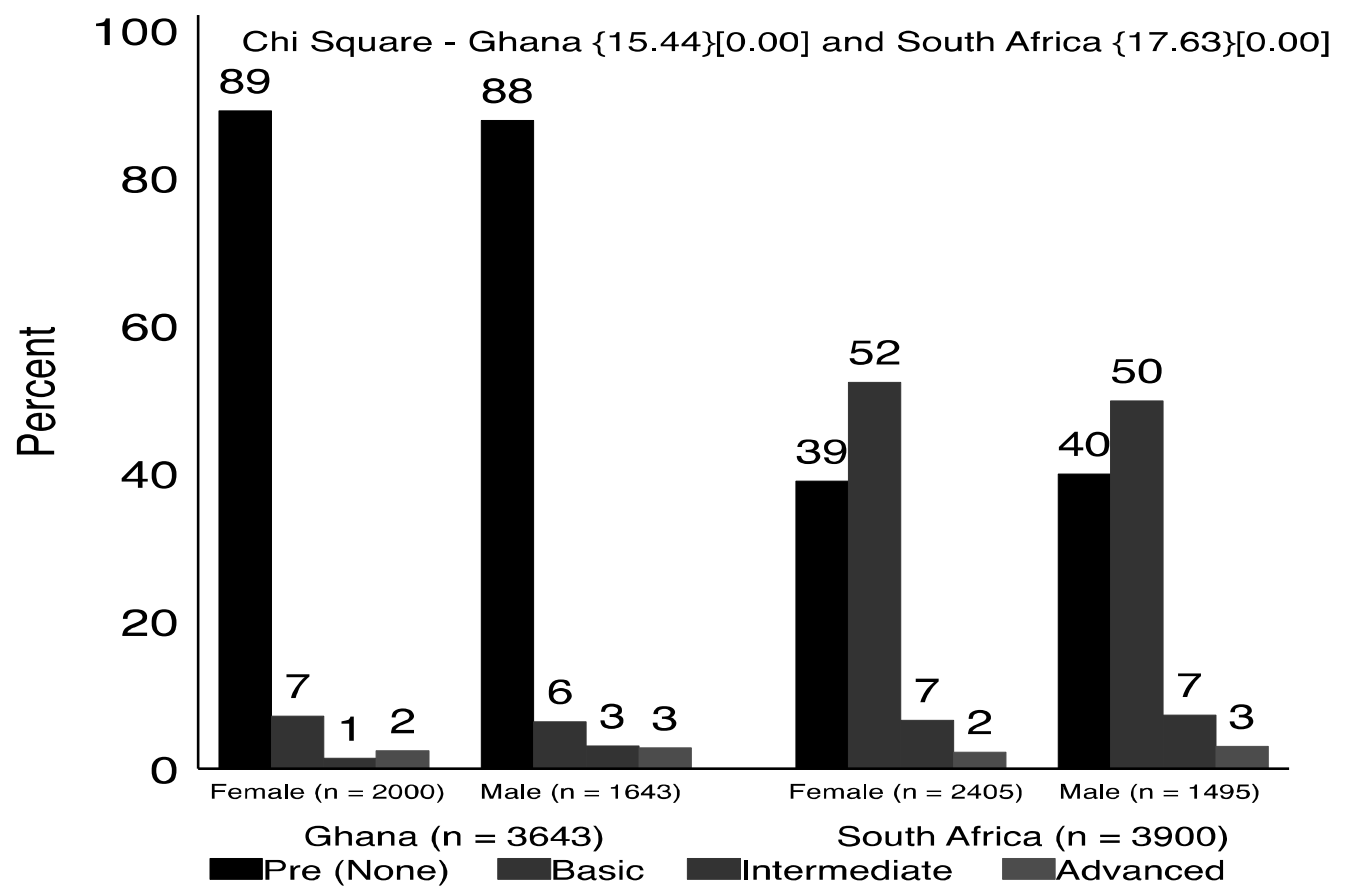

Figure 2: Levels of Use of Investment Products by Sex in Ghana and South Africa in 2010 


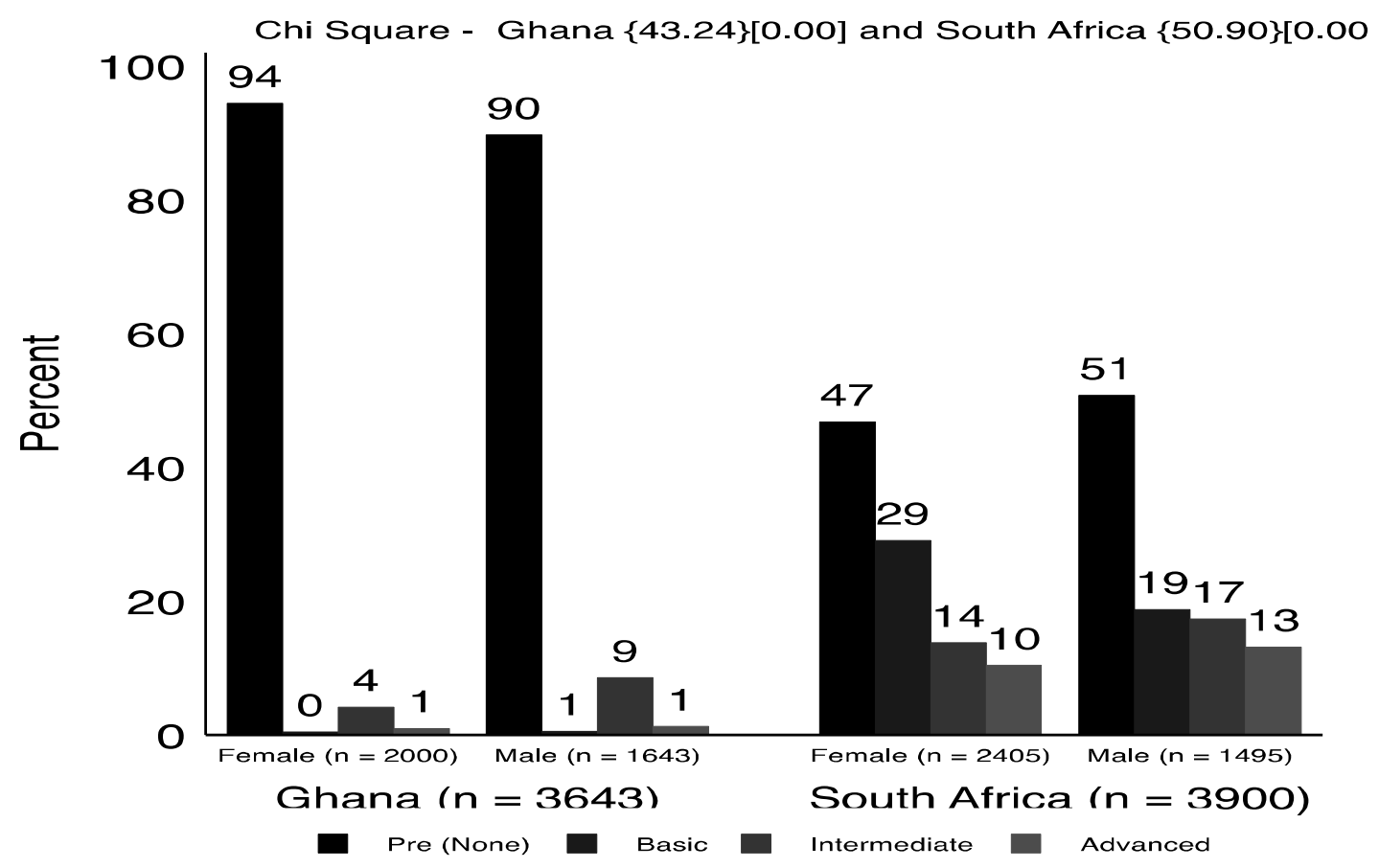

Figure 3: Levels of Use of Insurance Products by Sex in Ghana and South Africa in 2010

Tables 4 and 5 present the ordered logit results for each of the three financial services in Ghana and South Africa respectively. The summary statistics of the variables used in the ordered logit models are presented in Appendix C. The two tables show that gender significantly influences the use of general accounts and services and insurance in both Ghana and South Africa. However, the estimated results fail to find evidence of differences in terms of the use of investment services across gender in either country. The sign for the female variable in Table 1 is consistent with $a$ priori expectations. According to the results, females are 29 percent less likely to use higher level general account and services and 44 per cent less likely to use higher level insurance services. However, females in South Africa are more likely to use general account and insurance services than their male counterparts. From Table 4, the odds of using general account are 26 percent higher for females than for males, and 54 per cent higher when considering insurance services. Thus the results show that females in Ghana are financially excluded, but we fail to find the same evidence from South Africa, thus observing heterogeneity among women from different geographical contexts. 
Table 4: Ordered Logit Estimation of Usage of Various Financial Services in Ghana

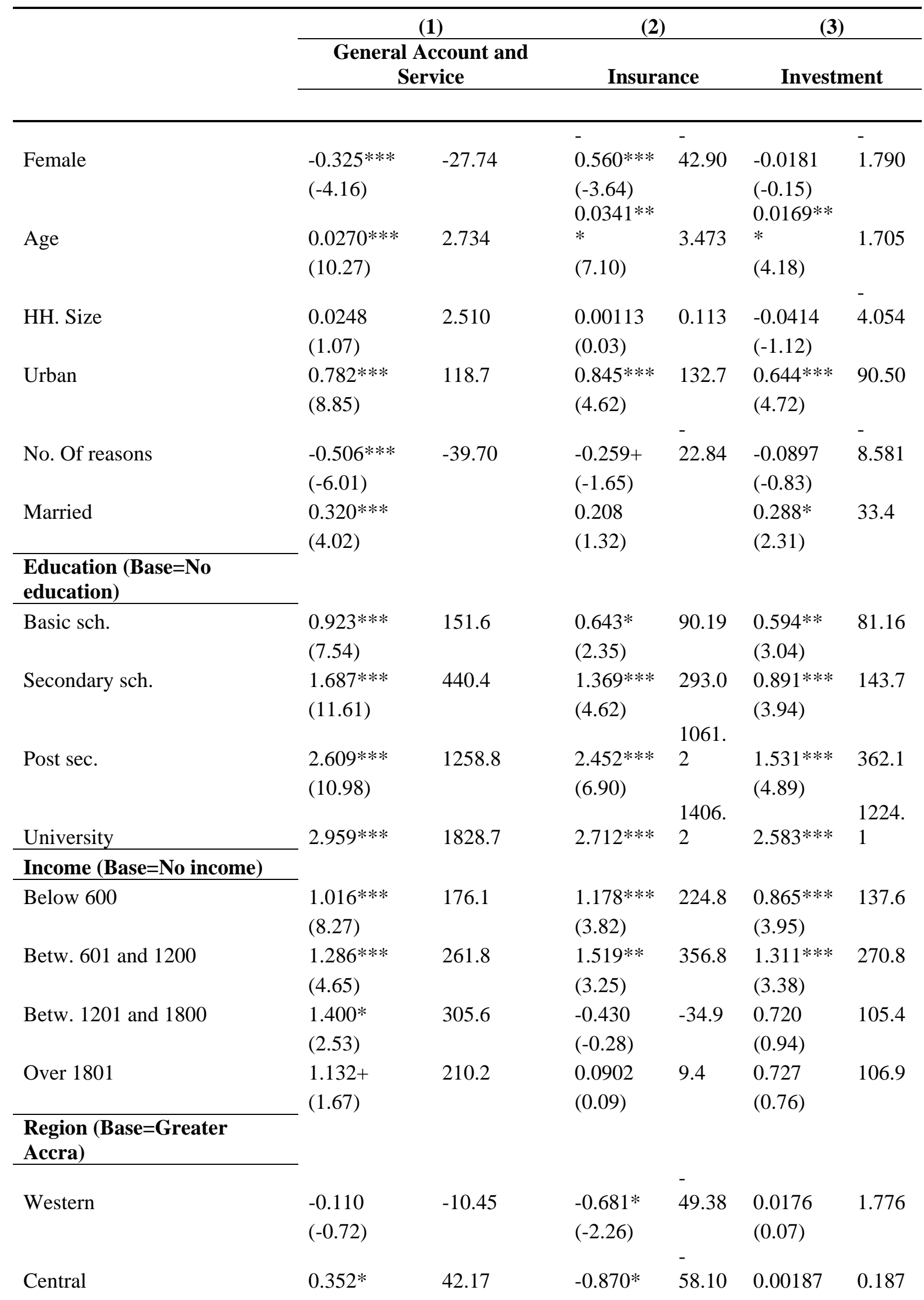


$(0.01)$

\begin{tabular}{|c|c|c|c|c|c|c|}
\hline Volta & $\begin{array}{l}-0.239 \\
(-1.38)\end{array}$ & -21.27 & $\begin{array}{l}0.0696 \\
(0.24)\end{array}$ & 7.213 & $\begin{array}{l}-0.0603 \\
(-0.20)\end{array}$ & $\begin{array}{l}- \\
5.848\end{array}$ \\
\hline Eastern & $\begin{array}{l}0.493^{* * *} \\
(3.35)\end{array}$ & 63.72 & $\begin{array}{l}-0.373 \\
(-1.31)\end{array}$ & $\begin{array}{l}- \\
31.11\end{array}$ & $\begin{array}{l}0.246 \\
(0.99)\end{array}$ & 27.84 \\
\hline Ashanti & $\begin{array}{l}0.424 * * * \\
(3.53)\end{array}$ & 52.74 & $\begin{array}{l}-0.204 \\
(-0.97)\end{array}$ & 18.49 & $\begin{array}{l}0.984 * * * \\
(5.46)\end{array}$ & 167.4 \\
\hline Brong Ahafo & $\begin{array}{l}0.152 \\
(0.89)\end{array}$ & 16.47 & $\begin{array}{l}-1.389 * * \\
(-2.81)\end{array}$ & $\overline{75.06}$ & $\begin{array}{l}-0.538 \\
(-1.47)\end{array}$ & $\overline{4} .61$ \\
\hline Northern & $\begin{array}{l}-0.976^{* * *} \\
(-4.90)\end{array}$ & -62.30 & $\begin{array}{l}-0.709 * \\
(-1.98)\end{array}$ & $\overline{5}-\overline{8} .81$ & $\begin{array}{l}0.548 * \\
(2.02)\end{array}$ & 72.97 \\
\hline Upper East & $\begin{array}{l}-0.352 \\
(-1.46)\end{array}$ & -29.69 & $\begin{array}{l}-0.205 \\
(-0.46)\end{array}$ & $\begin{array}{l}- \\
18.57\end{array}$ & $\begin{array}{l}0.823^{*} \\
(2.42)\end{array}$ & 127.8 \\
\hline Upper West & $\begin{array}{l}-0.650+ \\
(-1.95) \\
\end{array}$ & -47.79 & $\begin{array}{l}-0.150 \\
(-0.26) \\
\end{array}$ & $\begin{array}{l}- \\
13.96\end{array}$ & $\begin{array}{l}0.586 \\
(1.30) \\
\end{array}$ & 79.77 \\
\hline \multicolumn{7}{|l|}{ cut1 } \\
\hline $\begin{array}{l}\text { Constant } \\
\text { cut2 }\end{array}$ & $3.443^{* * *}$ & & $5.841^{* * *}$ & & $4.851^{* * *}$ & \\
\hline $\begin{array}{l}\text { Constant } \\
\text { cut3 }\end{array}$ & $5.095 * * *$ & & $5.922 * * *$ & & $5.925^{* * *}$ & \\
\hline Constant & $7.393^{* * *}$ & & $8.304^{* * *}$ & & $6.626^{* * *}$ & \\
\hline $\mathrm{N}$ & 3072 & & 3072 & & 3072 & \\
\hline
\end{tabular}

Percentage change in second column $\mathrm{z}$ statistics in parentheses $="+p<0.1$ $* \mathrm{p}<0.05 \quad * * \mathrm{p}<0.01 \quad * * * \mathrm{p}<0.001 "$

We observe that age is a significant determinant of the use of all the products in Ghana. In the case of South Africa, age is significant only in explaining the use of insurance services. From Table 5, a unit increase in age is associated with about a 3 percent chance that the person will use a higher level of general account and services and insurance, and about a 2 percent chance that they will use a higher level investment service in Ghana. For South Africa, on the other hand, the odds of using insurance services increase by 3 per cent per unit with increase in age. These findings are consistent with earlier works by Annim et al. (2012) and Barslund and Tarp (2008). 
Education is highly significant in explaining the levels of use of financial services in both Ghana and South Africa. The effect of education is confirmed in all the models except the investment model of South Africa. The signs of the set of education dummies are consistent with a priori expectations, that educated people are more likely to use higher levels of these financial services. However other studies do provide contrary evidence, where professional female investors are inclined to be more risk-averse than male fund managers (Bliss and Potter 2002; Olsen and Cox 2001), pointing to the gendered nature of risk aversion even with higher levels of human and educational qualifications. However it is important to note while gender differences appear to influence perceptions of risk and recommendations to clients, these differences tend to be the most significant for assets and portfolios at risk extremes.

A dummy variable (urban) was introduced to capture the rural-urban divide. In these countries, as in the case of most African countries, rural areas are inhabited by poor agrarian sections whose demand for financial services may be constrained by their socioeconomic conditions such as low income or the absence of financial institutions. However, residing in an urban area proves to increase the chance in the usage of higher levels all the financial services and general account and investment services in South Africa. To examine the effect of being married on the use of these financial services, a marriage dummy was introduced in the model. In both countries, this variable is significant in some of the models. For example, in Ghana being married increases the usage of an investment account by nearly 33.4 per cent. In South Africa, on the other hand, married people have about a 94 percent higher chance of using general account and services and a 90 percent chance of using an insurance service. Intuitively, this signpost that social responsibilities and perceptions of ensuing risks compel increased usage of financial services among women, particularly in taking up insurance products. 
Table 5: Ordered Logit Estimation of Usage of Various Financial Services in South Africa

\begin{tabular}{|c|c|c|c|c|c|c|}
\hline & \multicolumn{2}{|c|}{ (1) } & \multicolumn{2}{|c|}{ (2) } & \multicolumn{2}{|c|}{ (3) } \\
\hline & \multicolumn{2}{|c|}{ General Account and Services } & \multicolumn{2}{|c|}{ Insurance } & \multicolumn{2}{|c|}{ Investment } \\
\hline & Coef & $\% \Delta$ & Coef & $\% \Delta$ & Coef & $\% \Delta$ \\
\hline Female & $\begin{array}{l}0.23^{*} \\
(2.15)\end{array}$ & 25.80 & $\begin{array}{l}0.43^{* * *} \\
(4.12)\end{array}$ & 54.36 & $\begin{array}{l}0.02 \\
(0.16)\end{array}$ & 1.72 \\
\hline Age & $\begin{array}{l}0.00 \\
(0.56)\end{array}$ & 0.237 & $\begin{array}{l}0.03^{* * * *} \\
(7.91)\end{array}$ & 3.461 & $\begin{array}{l}0.00 \\
(0.41)\end{array}$ & 0.17 \\
\hline HH. Size & $\begin{array}{l}-0.01 \\
(-0.31)\end{array}$ & -0.737 & $\begin{array}{l}-0.02 \\
(-0.75)\end{array}$ & -1.914 & $\begin{array}{l}0.01 \\
(0.26)\end{array}$ & 0.56 \\
\hline Urban & $\begin{array}{l}0.405^{* *} \\
(3.10)\end{array}$ & 49.99 & $\begin{array}{l}-0.15 \\
(-1.18)\end{array}$ & -14.16 & $\begin{array}{l}-0.21+ \\
(-1.66)\end{array}$ & -18.79 \\
\hline No. of Reason & $\begin{array}{l}0.01 \\
(0.06)\end{array}$ & 0.726 & $\begin{array}{l}-0.195+ \\
(-1.81)\end{array}$ & -17.71 & $\begin{array}{l}-0.06 \\
(-0.59)\end{array}$ & -5.90 \\
\hline Married & $\begin{array}{l}0.66^{* * *} \\
(5.94)\end{array}$ & 94.30 & $\begin{array}{l}0.64^{* * *} \\
(5.80)\end{array}$ & 89.70 & $\begin{array}{l}0.06 \\
(0.49)\end{array}$ & 5.70 \\
\hline \multicolumn{7}{|l|}{ Education } \\
\hline High sch. & $\begin{array}{l}0.85^{* * *} \\
(4.98)\end{array}$ & 132.90 & $\begin{array}{l}0.51^{* *} \\
(3.11)\end{array}$ & 66.51 & $\begin{array}{l}0.05 \\
(0.31)\end{array}$ & 5.10 \\
\hline Technical sch. & $\begin{array}{l}2.13^{* * *} \\
(5.79)\end{array}$ & 741.70 & $\begin{array}{l}1.35^{* * *} \\
(3.30)\end{array}$ & 286.70 & $\begin{array}{l}-0.37 \\
(-0.96)\end{array}$ & -30.98 \\
\hline Matriculation/Univ. & $\begin{array}{l}1.55^{* * * *} \\
(8.76)\end{array}$ & 372.70 & $\begin{array}{l}1.11^{* * *} \\
(5.83)\end{array}$ & 202.10 & $\begin{array}{l}-0.15 \\
(-0.85)\end{array}$ & -14.01 \\
\hline \multicolumn{7}{|l|}{ Income (No income) } \\
\hline Below Average & $\begin{array}{l}0.63^{* *} \\
(3.20)\end{array}$ & 87.23 & $\begin{array}{l}0.40 * \\
(2.07)\end{array}$ & 49.44 & $\begin{array}{l}-0.23 \\
(-1.44)\end{array}$ & -20.79 \\
\hline Average Inc. & $\begin{array}{l}1.36 * * * \\
(6.64)\end{array}$ & 289.20 & $\begin{array}{l}0.77 * * * \\
(3.87)\end{array}$ & 116.0 & $\begin{array}{l}0.05 \\
(0.33)\end{array}$ & 5.540 \\
\hline Above Av. Inc. & $\begin{array}{l}1.79 * * * \\
(9.41)\end{array}$ & 501.40 & $\begin{array}{l}1.57 * * * \\
(8.46)\end{array}$ & 381.60 & $\begin{array}{l}0.16 \\
(1.02)\end{array}$ & 17.41 \\
\hline High inc. & $\begin{array}{l}3.80 * * * \\
(14.89)\end{array}$ & 4352.40 & $\begin{array}{l}4.20 * * * \\
(17.65)\end{array}$ & 6566.20 & $\begin{array}{l}0.44^{*} \\
(2.18)\end{array}$ & 55.94 \\
\hline \multicolumn{7}{|l|}{ Province } \\
\hline Eastern Cape & $\begin{array}{l}-0.34+ \\
(-1.93)\end{array}$ & -28.89 & $\begin{array}{l}-0.34+ \\
(-1.72)\end{array}$ & -28.46 & $\begin{array}{l}-0.01 \\
(-0.04)\end{array}$ & -0.831 \\
\hline Northern Cape & $\begin{array}{l}-0.38+ \\
(-1.86)\end{array}$ & -31.67 & $\begin{array}{l}-0.34 \\
(-1.56)\end{array}$ & -28.51 & $\begin{array}{l}-1.50 * * * \\
(-6.00)\end{array}$ & -77.60 \\
\hline Free State & $\begin{array}{l}-0.36+ \\
(-1.89)\end{array}$ & -30.45 & $\begin{array}{l}-0.33 \\
(-1.47)\end{array}$ & -27.87 & $\begin{array}{l}0.39 * \\
(2.26)\end{array}$ & 48.19 \\
\hline KwaZulu-Natal & $\begin{array}{l}-0.18 \\
(-1.01)\end{array}$ & -16.55 & $\begin{array}{l}-0.44^{*} \\
(-2.28)\end{array}$ & -35.87 & $\begin{array}{l}0.16 \\
(0.86)\end{array}$ & 17.31 \\
\hline North West & $\begin{array}{l}0.03 \\
(0.12)\end{array}$ & 2.926 & $\begin{array}{l}-0.67 * * \\
(-2.62)\end{array}$ & -48.63 & $\begin{array}{l}-0.58^{*} \\
(-2.52)\end{array}$ & -43.89 \\
\hline Gauteng & $\begin{array}{l}-0.19 \\
(-1.02)\end{array}$ & -17.31 & $\begin{array}{l}-0.25 \\
(-1.34)\end{array}$ & -22.24 & $\begin{array}{l}0.18 \\
(1.03)\end{array}$ & 20.10 \\
\hline
\end{tabular}




\begin{tabular}{|c|c|c|c|c|c|c|}
\hline Mpumlanaga & $\begin{array}{l}0.14 \\
(0.60)\end{array}$ & 14.51 & $\begin{array}{l}-0.78 * * \\
(-3.10)\end{array}$ & -54.09 & $\begin{array}{l}0.22 \\
(1.05)\end{array}$ & 24.27 \\
\hline Limpopo & $\begin{array}{l}-0.28 \\
(-1.34) \\
\end{array}$ & -24.62 & $\begin{array}{l}-0.87 * * * \\
(-3.71)\end{array}$ & -58.19 & $\begin{array}{l}-0.32 \\
(-1.38)\end{array}$ & -27.25 \\
\hline \multicolumn{7}{|l|}{ cut1 } \\
\hline $\begin{array}{l}\text { Constant } \\
\text { cut } 2\end{array}$ & \multicolumn{2}{|l|}{$2.37 * * *$} & \multicolumn{2}{|l|}{$2.97 * * *$} & \multicolumn{2}{|l|}{-0.42} \\
\hline $\begin{array}{l}\text { Constant } \\
\text { cut3 }\end{array}$ & \multicolumn{2}{|l|}{$3.50 * * *$} & \multicolumn{2}{|l|}{$5.06^{* * *}$} & \multicolumn{2}{|l|}{$2.54^{* * *}$} \\
\hline Constant & \multicolumn{2}{|l|}{$7.17^{* * *}$} & \multicolumn{2}{|l|}{$6.92^{* * *}$} & \multicolumn{2}{|l|}{$4.00 * * *$} \\
\hline $\mathbf{N}$ & \multicolumn{2}{|l|}{3123} & \multicolumn{2}{|l|}{3123} & \multicolumn{2}{|l|}{3123} \\
\hline \multicolumn{7}{|c|}{$\begin{array}{l}\text { Percentage change in second column } \\
\text { z statistics in parentheses }\end{array}$} \\
\hline$+p<0.1$ & $* p<0.05$ & $* * p<0.01$ & \multicolumn{3}{|c|}{$* * * p<0.001$} & \\
\hline
\end{tabular}

In terms of income, we observe that individuals with higher income levels compared with those with no income consistently show a positive and significant effect on the use of the various financial services across all models in the two countries. The finding of a positive and significant effect of income on the use of financial services is interpreted in the context of association in view of the potential bi-causal relationship. This may also means that increasing women's income may have a impact on use of higher level of financial services, an important finding emerging from our study. We also observe regional variation across countries and models. Compared to people in the Upper West region, inhabitants of the Central, Greater Accra, Eastern, Ashanti and Brong Ahafo regions are likely to use general accounting services. The situation is no different in South Africa, where the Western Cape is the reference province.

The analysis also included the impact of race on the use of financial services, focussing on the four main racial groups in South Africa. Thus race dummies was used to capture the effect of racial heterogeneity. We ran two separate models for South Africa, which is with and without race, for the sake of comparability (See Appendix 1). The results of the model are presented as Appendix B. Using Blacks as the reference group, this paper show that the three other groups, i.e. Coloured, Asian and White, are more likely to use higher levels of these financial products. This 
reiterates the persistent inequalities between racial groups in the country, although the paper does not attempt to focus on the effects of gender and race in the use of financial services. What is important is that the legacy of apartheid is still evident in the lack of opportunities for the majority of Black Africans in the 'rainbow' nation. For Johnson (2010) the fallacies of nationalist policies and flawed leadership continue to perpetuate social inequalities, and as Beinart and Dubow (1994) write, the legacy of apartheid in South Africa is indelible. It may be that policies are required to include the impact on different racial groups as part of the drive towards financial inclusion, in order to avoid the effects of the racialized processes in the American foreclosure crises (Rugh and Massey 2012). More research is required into the intersecting effects of social divisions based on race, class and gender on the access and use of formal financial services.

In line with the second objective of decomposing the coefficient of gender to identify the relative contributions by economic characteristics and behavioural differences, we employed the nonlinear version of the Blinder-Oaxaca decomposition technique (Sinning et al. 2008). The results of the decomposition for the various models are presented in Appendices D1 to D9. The results show that more 70 percent of the coefficient of female in the general account and insurance models is explained by unobserved characteristics across gender. In the case of investment services, about 47 percent of the gender differences are explained by unobserved characteristics. This implies that the variation across gender in terms of financial use is explained by factors other than what has been included in the model. Some of these factors point to differences in gendered behaviour, attitudes to financial risk taking as well as socioeconomic factors. This is in line with earlier studies that have found that women are generally more risk averse than males, although we argue that it is important to situate this through a deconstruction of the nature of risk vis-à-vis understanding social and gendered relations. 


\section{Conclusions}

The question of the 'sub-altern' financial subject, mainly women and racial minorities is gaining more prominence, and made more stark through the effects of the global financial crises. Roberts (2015) interrogates the multiple ways in which gender is mediated through the global agenda of public and private institutions that seek to extend finance, and position women as economic saviours for a gender equality agenda or a 'womenomics' approach. Her paper raises concerns on the existing social relations of finance, and the increasing commodification of women's bodily capacities through increasing economic opportunities for women. Allon (2014) also raises concerns about the increasing feminisation of finance where the constitution of women are interpellated as financial subjects, and targeted for financial products and services, reconfiguring ways in which financial capitalism operates at the level of domesticity. As seen generalizations in the literature on enhancing women's inclusion in finance ricochet from demand, to supply of financial services and that women are more prone to risk aversion, this paper sets out to examine these.

This paper has used FinScope data to examine gender differentials in access to and use of financial products in Ghana and South Africa. The rationale was to contribute to the debates on exhaustive, but mixed evidence on the gendered relationship with finance, and to identify the sources of the gender differentials, if any. Surveying the literature on gendered access to different types of formal finance, the paper contributes to investigating the presence of gender differentials in the use of higher order financial services. Not surprisingly, gender, levels of education, income levels, age, regional divides, racial status in South Africa and marital status do determine access to, and and the use of different types of financial services. It is evident that intersecting social divisions such as race and gender matter in the current drive towards financial inclusion. 
The evidence of gender differentials in both Ghana and South Africa is statistically supported in the case of general accounts and services, and insurance products. In addition to this, the main observation is that females in South Africa are more likely to use general financial and investment products than in Ghana. Based on a stepwise regression analysis, we observed that in South Africa, the income effect offsets the observation from the descriptive analysis that more males use financial services. This indicated that efforts to bridge the gender income gap need to be addressed in Ghana to promote sustainable use of financial service by all groups of women.

The study offers a platform for future research in addressing the issue of endogeneity due to the bi-causal relationship between income and the use of financial services and on the contribution of the individual variables to the observed differences in the coefficient of gender. As in most developing contexts, many African countries are pursuing financial inclusion as a key development goal, as an end in itself but also as means to many ends, that enables social and economic objectives particularly in the post 2015 agenda (UNCDF 2015). Thus the findings of the paper contributes to increased understanding on the levels and types of financial transactions among women in these two countries, and for developing appropriate financial products and policies that serve to fulfil the Sustainable Development Goals (SDGs) through enabling greater levels of financing in scale, scope and quality, and implement its gender equality objectives. Most importantly, lessons from the micrcofinance or financial systems approach to development must not be forgotten whilst pursuing a global agenda of financial deepening that targets women as financial subjects. As Mayoux (2001) argues group based lending models of microfinance has focussed on targeting women on the grounds of high female repayment rates and the need to stimulate women's economic activity for economic growth within the rhetoric of women's empowerment, rather than focussing on practical design of loan products that is appropriate to women's needs. 
The role of race is also evident in the case of South Africa, although the relationship between race and gender is beyond the scope of this paper. Evidence from the American foreclosure crises point to a racialized process from loan origination, institutional discrimination, residential segregation and historical dearth of access to capital, leading to predatory lending among minority dominant neighbourhoods (Immergluck 2009; Rugh and Massey 2010).

Thus non-financial approaches for tackling gender differences are required to tackle gender biases in policy approaches. This moves away from a biological basis for observed differences in financial risk taking and deconstructs observed gender differences within the wider framework of social relations, that situate women's decision to prioritise investments and the use of financial services that cover social risks, rather than mere participation in higher economic returns. As Marlow and Swail (2014) point out 'an association between gender,women and risk avoidance informs a valorization process which axiomatically presumes women are overly cautious and indeed disadvantageous' pointing to women as a 'limited' actor in the wider economic and financial field. For them, risk should be interpreted beyond the narrow measure of financial risk, where gender inclusive analyses can eradicate existing biases in the literature which define women as the antonym of the risk-taker (own emphasis). Thus current global discourses on financial inclusion should speak to, and reflect concerns raised by gender discourses in relation to biases in policies and practices that affect women's meaningful take up and use of financial services. This includes non-financial approaches that deconstruct complex social relations in financial behaviours, as well as tackle the gendered organisation of global finance and in the re-framing of gender sensitive financial policies and products. 


\section{References}

Abdulai, A.G and Hulme. D 2014. The politics of regional inequality in Ghana: State elites, donors and PRSPs. 1 October,. ESID Working Paper No. 41. http://www.effective-states.org/wpcontent/uploads/working_papers/final-pdfs/esid_wp_41_abdulai_hulme.pdf.

Allon, F. 2014. The feminisation of finance: gender, labour and the limits of inclusion. Australian Feminist Studies.

Annim, S., Arun, T., and Kostov, P. 2012. Effect of perceptions and behaviour on access to and use of financial service: Evidence from South Africa. IZA Discussion Paper series No 7042, Bonn.

Anselmi, D. L., \& Law, A. L. 1998. Questions of gender: Perspectives and paradoxes. McGrawHill Humanities Social.

Assassi, L. (2009). The Gendering of Global Finance. Springer.

Aterido R., Beck T. and Iacovone L. 2011. Gender and Finance in Sub-Saharan Africa: Are Women Disadvantaged? Policy Research Working Paper 5571. The World Bank Washington .

Barbarin, O. A., \& Richter, L. M. (2013). Mandela's children: Growing up in post-apartheid South Africa. Routledge.

Barslund, M., and Tarp, F. 2008. Formal and informal rural credit in four provinces of Vietnam. The Journal of Development Studies, 44(4), 485-503.

Bawumia, M., Owusu-Danso, T., \& McIntyre, A. 2008. Ghana’s reforms transform its financial sector. IMF Survey Magazine: Countries \& Region, 1-4.

Beck, U. 2006. Risk society revisited. The risk society and beyond.

Beinart, W and Dubow. 1994. Segregation and Apartheid in 20th Century South Africa. Editors. Routledge

Bliss, R. T., \& Potter, M. E. 2002. Mutual fund managers: does gender matter?. The Journal of Business and Economic Studies, 8(1), 1.

Brush, C. G., \& Cooper, S. Y. 2012. Female entrepreneurship and economic development: An international perspective. Entrepreneurship \& Regional Development, 24(1-2), 1-6.

Caliendo, M., Fossen, F. M., and Kritikos, A. S. 2009. Risk attitudes of nascent entrepreneurs-new evidence from an experimentally validated survey. Small Business Economics, 32(2), 153-167. 
Chant, S., \& Sweetman, C. 2012. Fixing women or fixing the world?'Smart economics', efficiency approaches, and gender equality in development.Gender \& Development, 20(3), 517-529.

Deghaye, N., McKenzie, T., and Chirawu, P. 2014. Inequality in South Africa: A two part document on the current understanding and dimensions of inequality in health, gender and livelihoods.

Doyle, J. A., and Paludi, M. A. 1991. Sex and gender: The human experience. William C. Brown.

Eckel, C. C., and Grossman, P. J. 2002. Sex differences and statistical stereotyping in attitudes toward financial risk. Evolution and human behavior,23(4), 281-295.

Finmark Trust. 2011. FinScope South Africa Small Business Survey 2010. Midrand: Finmark Trust.

Heintz, J. 2005. Employment, poverty, and gender in Ghana. PERI Working Papers, 66.

Immergluck, D. 2009. Core of the crisis: Deregulation, the global savings glut, and financial innovation in the subprime debacle. City \& Community,8(3), 341-345.

Jianakoplos, N. A., and Bernasek, A. 1998. Are women more risk averse?.Economic inquiry, 36(4), 620-630.

Johnson, R.W. 2010. South Africa's brave new world: The beloved country since the end of Apartheid: London: Penguin books.

Kehler, J. 2001. Women and Poverty: The South African Experience. Journal of International Women's Studies, 3(1), 41-53. Available at: http://vc.bridgew.edu/jiws/vol3/iss1/3

Kostov, P., Arun, T., and Annim, S. 2011. Determinants of access to finance: an investigation into the Mzansi intervention. European Journal of Development Research, 24(3), 397-412.

Kuada, J. 2009. Gender, social networks, and entrepreneurship in Ghana. Journal of African Business, 10(1), 85-103.

Marlow, S., \& Swail, J. 2014. Gender, risk and finance: why can't a woman be more like a man?. Entrepreneurship \& Regional Development, 26(1-2), 80-96.

May, J. 1998. The Experience and Perception of Poverty in South Africa. Praxis Publishing: Durban. 
Maurer, B (2005) Finance, in James Carrier (ed.) A Handbook of Economic Anthropology, Edward Elgar. Cheltenham, pp176-193.

Mayoux, L. 2001. Tackling the down side: Social capital, women's empowerment and microfinance in Cameroon. Development and change,32(3), 435-464.

Meier-Pesti, K., and Penz, E. 2008. Sex or gender? Expanding the sex-based view by introducing masculinity and femininity as predictors of financial risk taking. Journal of Economic Psychology, 29(2), 180-196.

Muravyev, A, Talavera, O and Schäfer, D, 2009. "Entrepreneurs' gender and financial constraints: Evidence from international data," Journal of Comparative Economics, Elsevier, vol. 37(2), 270286, June.

Narain, S 2009. Gender and Access to Finance. Analytical Paper, World Bank. Retrieved from http://siteresources.worldbank.org/EXTGENDERSTATS/Resources/SushmaNarain-

AccesstoFinanceAnalyticalPaper.doc

Olsen, R. A., and Cox, C. M. 2001. The influence of gender on the perception and response to investment risk: The case of professional investors. The journal of psychology and financial markets, 2(1), 29-36.

Powell, M., \& Ansic, D. 1997. Gender differences in risk behaviour in financial decision-making: An experimental analysis. Journal of economic psychology, 18(6), 605-628.

Roberts, A. (2015). Gender, financial deepening and the production of embodied finance: Towards a critical feminist analysis. Global Society, 29(1), 107-127.

Rugh, J. S., and Massey, D. S. 2010. Racial segregation and the American foreclosure crisis. American Sociological Review, 75(5), 629-651.

Sapienza, P., Zingales, L., and Maestripieri, D. 2009. Gender differences in financial risk aversion and career choices are affected by testosterone. Proceedings of the National Academy of Sciences, 106(36), 15268-15273.

Schubert, R. 2006. Analyzing and managing risks-on the importance of gender differences in risk attitudes. Managerial Finance, 32(9), 706-715.

Shaw, E., Carter, S. and Lam, W. 2010. An integrated View of Gender, Finance and Entrepreneurial Capital: Theory, Practice and Policy. In Women Entrepreneurs and the Global Environment for Growth. de Bruin, A., Brush, C.G., Gatewood, E.J. \& Hendry C. Cheltenham, UK: Edward Elgar Publishing. 187-205.

Sinning, M., Hahn, M., \& Bauer, T. K. 2008. The Blinder-Oaxaca decomposition for nonlinear regression models. The Stata Journal, 8(4), 480-492. 
UNCDF. 2015. A means to an end: The post-2015 future of financial inclusion.

http://www.uncdf.org/en/means-end-post-2015-future-financial-inclusion. Accessed March 2016.

UNDP. 2014. The impacts of social AND economic inequality on economic development in South Africa.

http://www.za.undp.org/content/dam/south_africa/docs/Reports/UNDP\%20Inequality\%20South \%20Africa.pdf. Accessed March 2016.

van Hulten, A. 2012. Women's access to SME finance in Australia. International Journal of Gender and Entrepreneurship, 4(3), 266-288.

Wilson, M., and Daly, M. 1985. Competitiveness, risk taking, and violence: The young male syndrome. Ethology and sociobiology, 6(1), 59-73.

\section{APPENDICES}

Appendix A3: Ordered Logit Estimation of Usage of Various Financial Services in South Africa - With Race

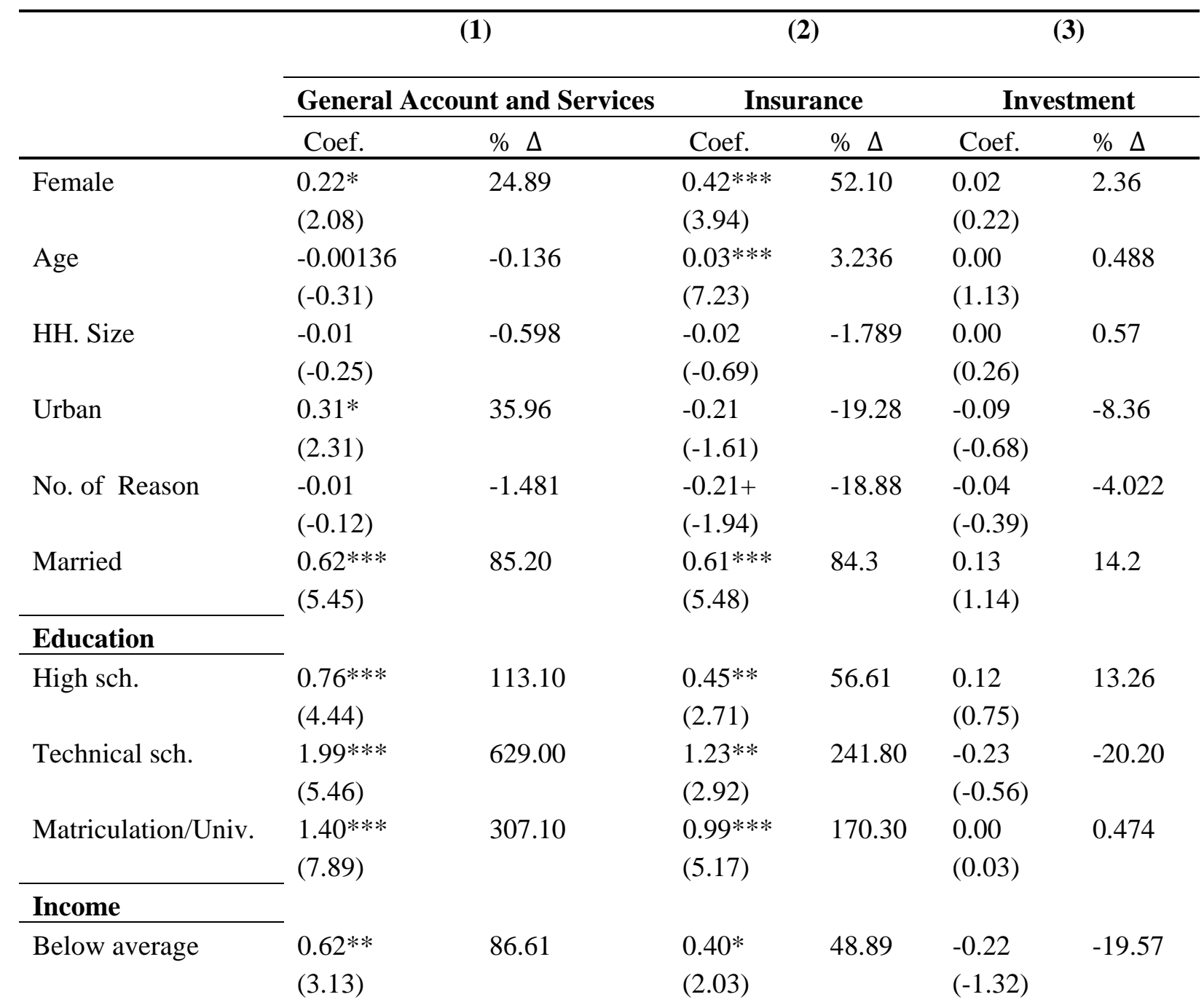




\begin{tabular}{|c|c|c|c|c|c|c|}
\hline Average inc & $\begin{array}{l}1.41 * * * \\
(6.85)\end{array}$ & 311.10 & $\begin{array}{l}0.79 * * * \\
(3.94)\end{array}$ & 120.90 & $\begin{array}{l}0.01 \\
(0.05)\end{array}$ & 0.90 \\
\hline above av. Inc & $\begin{array}{l}1.86^{* * *} \\
(9.54)\end{array}$ & 544.00 & $\begin{array}{l}1.59 * * * \\
(8.41)\end{array}$ & 390.70 & $\begin{array}{l}0.13 \\
(0.81)\end{array}$ & 13.61 \\
\hline High inc. & $\begin{array}{l}3.74 * * * \\
(14.63)\end{array}$ & 4103.70 & $\begin{array}{l}4.17 * * * \\
(17.44)\end{array}$ & 6337.20 & $\begin{array}{l}0.58 * * \\
(2.77)\end{array}$ & 78.75 \\
\hline \multicolumn{7}{|l|}{ Province } \\
\hline Eastern cape & $\begin{array}{l}-0.14 \\
(-0.75)\end{array}$ & -12.79 & $\begin{array}{l}-0.31 \\
(-1.64)\end{array}$ & -26.91 & $\begin{array}{l}-0.28 \\
(-1.46)\end{array}$ & -24.49 \\
\hline Northern Cape & $\begin{array}{l}-0.37+ \\
(-1.80)\end{array}$ & -30.81 & $\begin{array}{l}-0.32 \\
(-1.46)\end{array}$ & -27.42 & $\begin{array}{l}-1.55^{* * *} \\
(-6.21)\end{array}$ & -78.84 \\
\hline Free State & $\begin{array}{l}-0.18 \\
(-0.89)\end{array}$ & -16.36 & $\begin{array}{l}-0.31 \\
(-1.40)\end{array}$ & -26.88 & $\begin{array}{l}0.10 \\
(0.51)\end{array}$ & 10.03 \\
\hline KwaZulu-Natal & $\begin{array}{l}-0.07 \\
(-0.34)\end{array}$ & -6.466 & $\begin{array}{l}-0.50^{*} \\
(-2.44)\end{array}$ & -39.34 & $\begin{array}{l}0.01 \\
(0.03)\end{array}$ & 0.700 \\
\hline North West & $\begin{array}{l}0.18 \\
(0.71)\end{array}$ & 19.41 & $\begin{array}{l}-0.69 * * \\
(-2.71)\end{array}$ & -49.60 & $\begin{array}{l}-0.82^{* * *} \\
(-3.36)\end{array}$ & -56.01 \\
\hline Gauteng & $\begin{array}{l}0.01 \\
(0.03)\end{array}$ & 0.54 & $\begin{array}{l}-0.24 \\
(-1.31)\end{array}$ & -21.51 & $\begin{array}{l}-0.12 \\
(-0.63)\end{array}$ & -11.25 \\
\hline Mpumlanaga & $\begin{array}{l}0.38 \\
(1.58)\end{array}$ & 45.48 & $\begin{array}{l}-0.75^{* *} \\
(-2.96)\end{array}$ & -52.61 & $\begin{array}{l}-0.11 \\
(-0.52)\end{array}$ & -10.70 \\
\hline Limpopo & $\begin{array}{l}-0.08 \\
(-0.35)\end{array}$ & -7.51 & $\begin{array}{l}-0.86 * * * \\
(-3.66)\end{array}$ & -57.83 & $\begin{array}{l}-0.60 * \\
(-2.53)\end{array}$ & -45.32 \\
\hline \multicolumn{7}{|l|}{ Race } \\
\hline Coloured & $\begin{array}{l}0.25 \\
(1.51)\end{array}$ & 28.02 & $\begin{array}{l}-0.03 \\
(-0.17)\end{array}$ & -2.81 & $\begin{array}{l}-0.49 * * \\
(-2.95)\end{array}$ & -38.66 \\
\hline Asian & $\begin{array}{l}0.87 * * * \\
(3.44)\end{array}$ & 137.60 & $\begin{array}{l}0.67+ \\
(1.94)\end{array}$ & 94.65 & $\begin{array}{l}-1.30 * * * \\
(-4.67)\end{array}$ & -72.85 \\
\hline White & $\begin{array}{l}1.07 * * * \\
(5.65)\end{array}$ & 191.40 & $\begin{array}{l}0.60 * * \\
(3.13)\end{array}$ & 81.67 & $\begin{array}{l}-1.04 * * * \\
(-4.88) \\
\end{array}$ & -64.68 \\
\hline \multicolumn{7}{|l|}{ cut1 } \\
\hline $\begin{array}{l}\text { Constant } \\
\text { cut2 }\end{array}$ & $2.36 * * *$ & & $2.82 * * *$ & & -0.50 & \\
\hline $\begin{array}{l}\text { Constant } \\
\text { cut3 }\end{array}$ & $3.49 * * *$ & & $4.91^{* * *}$ & & $2.51 * * *$ & \\
\hline Constant & $7.27 * * *$ & & $6.80 * * *$ & & $3.10^{* * *}$ & \\
\hline $\mathbf{N}$ & 3123 & & 3123 & & 3123 & \\
\hline \multicolumn{7}{|c|}{$\begin{array}{l}\text { Percentage change in second column } \\
\text { z statistics in parentheses }\end{array}$} \\
\hline
\end{tabular}


Appendix D1: Decomposition of general account and services - South Africa

\begin{tabular}{lllll}
\hline & Coef & Percentage & Std. Err & Z \\
\hline Explained & -0.11 & 3451.13 & 0.03 & -3.96 \\
Unexplained & 0.11 & -3351.13 & 0.06 & 1.75 \\
Total & 0.00 & 100.00 & 0.07 & -0.05 \\
\hline
\end{tabular}

Note: Bootstrap standard errors; 100 repetitions

Appendix D2: Decomposition of insurance model - South Africa

\begin{tabular}{lllll}
\hline & Coef & Percentage & Std. Err & Z \\
\hline Explained & -0.11 & 1086.52 & 0.02 & -5.00 \\
Unexplained & 0.10 & -986.52 & 0.06 & 1.68 \\
Total & -0.01 & 100.00 & 0.07 & -0.15 \\
\hline
\end{tabular}

Note: Bootstrap standard errors; 100 repetitions

Appendix D3: Decomposition of investment model - South Africa

\begin{tabular}{lllll}
\hline & Coef & Percentage & Std. Err & Z \\
\hline Explained & -0.01 & 10.91 & 0.02 & -0.63 \\
Unexplained & -0.12 & 89.09 & 0.15 & -0.78 \\
Total & -0.13 & 1.00 & 0.15 & -0.9 .00 \\
\hline
\end{tabular}

Note: Bootstrap standard errors; 100 repetitions

Appendix D4: Decomposition extended general account and services model-South Africa

\begin{tabular}{lllll}
\hline & Coef & Percentage & Std. Err & Z \\
\hline Explained & -0.12 & 406.08 & 0.02 & -4.85 \\
Unexplained & 0.09 & -306.08 & 0.06 & 1.42 \\
Total & -0.03 & 100.00 & 0.07 & -0.42 \\
\hline
\end{tabular}

Note: Bootstrap standard errors; 100 repetitions 
Appendix D5: decomposition extended insurance model-South Africa

\begin{tabular}{lllll}
\hline & Coef & Percentage & Std. Err & Z \\
\hline Explained & -0.12 & 1322.90 & 0.03 & -4.35 \\
Unexplained & 0.11 & -1222.90 & 0.06 & 1.70 \\
Total & -0.01 & 100.00 & -0.12 & 0.91 \\
\hline
\end{tabular}

Note: Bootstrap standard errors; 100 repetitions

Appendix D6: Decomposition of extended investment model-South Africa

\begin{tabular}{lllll}
\hline & Coef & Percentage & Std. Err & Z \\
\hline Explained & 0.00 & 8.33 & 0.02 & -0.18 \\
Unexplained & -0.05 & 91.67 & 0.14 & -0.32 \\
Total & -0.05 & 100.00 & 0.14 & -0.35 \\
\hline
\end{tabular}

Note: Bootstrap standard errors; 100 repetitions

Appendix D7: Decomposition of general account and services model-Ghana

\begin{tabular}{lllll}
\hline & Coef & Percentage & Std. Err & Z \\
\hline Explained & -0.06 & 32.36 & 0.02 & -3.14 \\
Unexplained & -0.12 & 67.64 & 0.04 & -2.87 \\
Total & -0.18 & 100.00 & 0.04 & -4.65 \\
\hline
\end{tabular}

Note: Bootstrap standard errors; 100 repetitions

Appendix D8: Decomposition of insurance model-Ghana

\begin{tabular}{lllll}
\hline & Coef & Percentage & Std. Err & Z \\
\hline Explained & -0.12 & 23.25 & 0.03 & -4.35 \\
Unexplained & 0.11 & 76.75 & 0.06 & 1.70 \\
Total & -0.24 & 100.00 & 0.09 & -2.67 \\
\hline
\end{tabular}

Note: Bootstrap standard errors; 100 repetitions

Appendix D9: Decomposition of investment model-Ghana

\begin{tabular}{lllll}
\hline & Coef & Percentage & Std. Err & Z \\
\hline Explained & -0.06 & 53.42 & 0.02 & -2.43 \\
Unexplained & -0.19 & 46.58 & 0.09 & -2.09 \\
Total & -0.24 & 100.00 & 0.09 & -2.67 \\
\hline
\end{tabular}

Note: Bootstrap standard errors; 100 repetitions 